\title{
OPINIE POLAKÓW O WSPÓŁPLACENIU ZA LECZENIE SZPITALNE ORAZ O DOPLATACH DO ŚWIADCZEŃ PONADSTANDARDOWYCH
}

\section{POLISH CITIZENS' OPINIONS CONCERNING CO-PAYMENT FOR HOSPITALIZATION AND SUBSIDIES FOR NON-STANDARD BENEFITS}

\author{
Katedra i Zakład Zdrowia Publicznego Pomorskiego Uniwersytetu Medycznego w Szczecinie \\ ul. Żołnierska 48, 71-210 Szczecin \\ Kierownik: prof. dr hab. n. zdr. Beata Karakiewicz \\ ${ }^{1}$ Samodzielna Pracownia Rehabilitacji Medycznej Pomorskiego Uniwersytetu Medycznego w Szczecinie \\ ul. Żołnierska 54, 71-210 Szczecin \\ Kierownik: dr n. med. Iwona Rotter
}

\begin{abstract}
Summary
Introduction: Co-payment in the health sector operates in most healthcare systems in European countries.

The aim of this study was knowledge of Polish citizens' opinions concerning healthcare services co-payment with respect to selected socio-demographic factors.

Material and methods: The study was conducted using a diagnostic survey of 636 respondents, representing residents of the West Pomeranian region, Poland.

Results: The majority of respondents did not accept co-payment for health services.

Conclusions: Material situation and educational background impact on decisions concerning co-payment for hospital treatment.
\end{abstract}

K e y w o r d s: hospitalization - patients - co-payment

\section{Streszczenie}

Wstęp: Współpłacenie jest rozwiązaniem systemowym funkcjonującym w sektorze ochrony zdrowia większości państw europejskich.

Celem pracy było poznanie opinii Polaków na temat współpłacenia w zależności od wybranych czynników socjodemograficznych

Materiat i metody: Badanie metodą sondażu diagnostycznego przeprowadzono wśród 636 mieszkańców zachodniopomorskiej Polski.
Wyniki: Większość respondentów nie wyraziła zgody na współpłacenie.

Wnioski: Sytuacja materialna i wykształcenie mają wpływ na opinie na temat wpółpłacenia za leczenie szpitalne.

H a s $\nmid$ a: leczenie szpitalne - pacjent - współpłacenie.

\section{Wstęp}

Współpłacenie jest rozwiązaniem systemowym funkcjonującym w sektorze ochrony zdrowia większości państw europejskich. Polega ono na współudziale pacjentów w pokrywaniu kosztów świadczonych im usług medycznych. Bezpośredni udział pacjentów w kosztach leczenia możliwy jest do zrealizowania w różnej postaci i na różnych płaszczyznach. Obecnie w Polsce powszechne jest pokrywanie częściowych kosztów pobytu w placówkach opiekuńczo-leczniczych i pielęgnacyjno-opiekuńczych. Biorąc pod uwagę fakt, że Polska boryka się z problemami finansowymi w sektorze ochrony zdrowia, zasada taka mogłaby obowiązywać również w szpitalach, zwłaszcza że leczenie szpitalne generuje również koszty dodatkowe związane z zakwaterowaniem i wyżywieniem. Forma współpłacenia za leczenie szpitalne funkcjonuje w Niemczech, gdzie opłata wynosi 10 euro za dzień (ale nie więcej niż za $28 \mathrm{dni}$ w ciągu roku). We Francji natomiast opłata ryczałtowa za dzień hospitalizacji wynosi 16 euro. System Wielkiej Brytanii dopuszcza partycypację pacjenta w kosztach pobytu 
w szpitalu, ale tylko za tzw. łóżka z udogodnieniami, czyli np. salę jednoosobową. Korzyści płynące $\mathrm{z}$ wprowadzenia współpłacenia zauważono w Czechach, gdzie wprowadzenie zasady partycypacji pacjentów w kosztach leczenia szpitalnego przyczyniło się do stosunkowo dużych wpływów finansowych, co zminimalizowało problem niedofinansowania systemu ochrony zdrowia.

Celem pracy było poznanie opinii Polaków na temat współpłacenia i ich gotowości do ponoszenia części kosztów związanych z zakwaterowaniem i wyżywieniem oraz dopłat do świadczeń wyższej jakości, np. za salę jednoosobową, w zależności od wybranych czynników socjodemograficznych.

\section{Materiał i metody}

Badanie obejmujące zachodniopomorski region Polski prowadzono od stycznia 2012 r. do lutego 2013 r. Udział wzięło 636 respondentów. Dobór próby miał charakter losowy. Zastosowano metodę wywiadu z autorskim kwestionariuszem ankiety skonstruowanej na podstawie analiz dotychczasowych badań dotyczących finansowania polskiego systemu ochrony zdrowia oraz własnych przemyśleń. Uzyskane wyniki poddane zostały analizie statystycznej $z$ wykorzystaniem testu $\chi^{2}$ Pearsona; przyjęto poziom istotności $\mathrm{p}<0,05$.

\section{Wyniki badań}

Większość respondentów (59,75\%) nie była skłonna do tego, aby pokryć część kosztów związanych z zakwaterowaniem i wyżywieniem. Zapytano również ankietowanych o gotowość wnoszenia dopłat do świadczeń wyższej jakości. W tym przypadku uzyskane odpowiedzi wskazują na niechęć respondentów - jedynie 41,51\% $\mathrm{z}$ nich wyraziło zgodę na ponoszenie dodatkowych kosztów. Uzyskane wyniki poddano weryfikacji statystycznej. Wyniki testu niezależności $\chi^{2}$ Pearsona $(p>0,05)$ wykazały brak istotnej zależności między wiekiem respondentów a deklarowaną zgodą na pokrywanie części kosztów. Wiek respondentów nie wpływał również istotnie statystycznie $(\mathrm{p}>0,05)$ na gotowość wnoszenia dopłat do świadczeń wyższej jakości. Chęć respondentów do uiszczania dopłat maleje wraz ze wzrostem poziomu wykształcenia. Otrzymano wyniki świadczące o statystycznie istotnej zależności pomiędzy badanymi cechami $(\mathrm{p}<0,05)$, co oznacza, że ankietowani z wyższym wykształceniem częściej wyrażają niechęć do wnoszenia dodatkowych opłat. Respondenci z wykształceniem średnim wyraźnie sprzeciwili się współpłaceniu za zakwaterowanie i wyżywienie. Za pomocą testu $\chi^{2}$ wykazano istotną zależność pomiędzy poziomem wykształcenia a chęcią na pokrycie części kosztów. Zarówno kobiety, jak i mężczyźni nie różnili się istotnie statystycznie $(\mathrm{p}>0,05)$ pod względem chęci do współpłacenia za wyżywienie i zakwaterowanie oraz uiszczenia dopłat do świadczeń wyższej jakości. Osoby gorzej sytuowane najczęściej wyrażały niechęć do ponoszenia części kosztów. Ankietowani określający swoją sytuację materialną jako bardzo złą w ogóle nie byli skłonni dopłacić do świadczeń wyższej jakości (tab. 1).

W obu przypadkach zmienne poddano weryfikacji statystycznej przy użyciu testu niezależności $\chi^{2}$ Pearsona. Otrzymane wyniki świadczą o tym, że występuje istotna statystycznie zależność $(p<0,05)$ pomiędzy subiektywną oceną sytuacji materialnej a akceptacją ponoszenia części kosztów związanych z zakwaterowaniem i wyżywieniem podczas pobytu w szpitalu oraz pomiędzy subiektywną oceną sytuacji materialnej a dopłatą do świadczeń wyższej jakości.

\section{Dyskusja}

Wyniki badań własnych wykazują, że większość badanych byłaby skłonna pokryć część kosztów związanych z zakwaterowaniem i wyżywieniem, natomiast, jak pokazuje raport z badań przeprowadzonych w 2011 r. na liczącej 1021 osób reprezentatywnej próbie losowej dorosłych mieszkańców Polski, zgodę na taką formę współpłacenia wyraziło tylko $24 \%$ badanych [1]. Wyniki badań przeprowadzonych w dniach 4-10.02.2010 r. przez Centrum Badania Opinii Społecznej (CBOS) wskazują, że wg 30\% $(n=1021)$ ankietowanych system ochrony zdrowia funkcjonuje źle i wymaga zdecydowanej poprawy [2]. Stwarza to konieczność poszukiwania radykalnych rozwiązań mających na celu poprawę istniejącej sytuacji. Stąd też specjaliści różnych

T a b e la 1. Sytuacja materialna a deklarowana zgoda na wspólpłacenie za leczenie szpitalne

\begin{tabular}{|c|c|c|c|c|c|c|}
\hline \multirow{2}{*}{$\begin{array}{l}\text { Sytuacja } \\
\text { materialna }\end{array}$} & \multicolumn{3}{|c|}{$\begin{array}{l}\text { Zgoda na ponoszenie części kosztów związanych } \\
\text { z zakwaterowaniem i wyżywieniem podczas pobytu w szpitalu }\end{array}$} & \multicolumn{3}{|c|}{$\begin{array}{c}\text { Zgoda na dopłaty do świadczeń wyższej jakości, } \\
\text { np. za salę jednoosobową }\end{array}$} \\
\hline & tak & nie & razem & tak & nie & razem \\
\hline Bardzo dobra & $4(0,63 \%)$ & $4(0,63 \%)$ & $8(1,26 \%)$ & $4(0,63 \%)$ & $4(0,63 \%)$ & $8(1,26 \%)$ \\
\hline Dobra & $60(9,43 \%)$ & $16(2,52 \%)$ & $76(11,95 \%)$ & $44(6,92 \%)$ & $32(5,03 \%)$ & $76(11,95 \%)$ \\
\hline Zadowalająca & $100(15,72 \%)$ & $184(28,93 \%)$ & $284(44,65 \%)$ & $160(25,15 \%)$ & $124(19,49 \%)$ & $284(44,64 \%)$ \\
\hline Bardzo zła & $16(2,52 \%)$ & $40(6,29 \%)$ & $56(8,81 \%)$ & $0(0 \%)$ & $56(8,81 \%)$ & $56(8,81 \%)$ \\
\hline Ogółem & $256(40,25 \%)$ & $380(59,75 \%)$ & $636(100 \%)$ & $264(41,51 \%)$ & $372(58,49 \%)$ & $636(100 \%)$ \\
\hline
\end{tabular}


dziedzin, począwszy od ekonomistów poprzez polityków, aż po specjalistów zarządzania w ochronie zdrowia, tworzą scenariusze różnego rodzaju działań mających na celu polepszenie sytuacji. Biorący udział w badaniu prowadzonym przez CBOS w większości twierdzili (59\%), że wprowadzenie dodatkowych opłat do świadczeń realizowanych w ramach powszechnego ubezpieczenia zdrowotnego nie poprawi sytuacji i jakości świadczeń. Badania własne natomiast pokazują, że gotowość respondentów do uiszczania dopłat do świadczeń wyższej jakości maleje wraz ze wzrostem poziomu wykształcenia. Najliczniejszą grupę ankietowanych biorących udział w badaniu własnym deklarującą gotowość do ponoszenia części kosztów stanowiły osoby, które oceniały swoją sytuację materialną jako wystarczającą.

W badaniach prowadzonych przez Rudawska, które dotyczyły m.in. motywów rezygnacji z dobrowolnego ubezpieczenia zdrowotnego, 55,17\% $(\mathrm{n}=317)$ ankietowanych wskazało jako powód barierę ekonomiczną [3]. Respondenci biorący udział w badaniach własnych, oceniający swoją sytuację jako złą i bardzo złą, z tego samego powodu nie wyrazili chęci partycypacji w kosztach zakwaterowania i wyżywienia podczas pobytu w szpitalu. Innym motywem niechęci wykupienia dobrowolnych ubezpieczeń zdrowotnych jest zadowolenie pacjentów z opieki gwarantowanej w ramach powszechnego obowiązkowego ubezpieczenia takiej odpowiedzi udzieliło 8,83\% [4]. Wyniki badań własnych wskazują, że to przede wszystkim sytuacja materialna jest czynnikiem wpływającym na skłonność wnoszenia dodatkowych opłat do świadczeń szpitalnych wyższej jakości, czyli na przykład za salę jednoosobową. Niechęć społeczeństwa dotycząca współpłacenia w dużej mierze wynika z niedoinformowania o korzyściach oraz o skutkach jego ominięcia w trakcie tworzenia kolejnych reform systemu ochrony zdrowia [5].

\section{Wnioski}

Większość respondentów nie wyraziła gotowości do współpłacenia za leczenie szpitalne, a ich wiek i płeć nie wpływa na gotowość pokrycia części kosztów związanych z zakwaterowaniem i wyżywieniem podczas pobytu w szpitalu i na gotowość dopłat do świadczeń wyższej jakości, natomiast wykształcenie i sytuacja materialna mają wpływ na decyzję w sprawie współpłacenia.

\section{Piśmiennictwo}

1. Aktualne problemy i wydarzenia. Opinie o funkcjonowaniu systemu opieki zdrowotnej. Centrum Badania Opinii Społecznej, Warszawa 2012.

2. Aktualne problemy i wydarzenia. Gotowość do zmian w służbie zdrowia. Raport z badań. Centrum Badania Opinii Społecznej, Warszawa 2010.

3. Rudawska I.: Opieka zdrowotna. Aspekty rynkowe i marketingowe. PWN, Warszawa 2007, 178-180.

4. Siwińska V., Brożyniak J., Itżecka J., Jarosz M. J., Orzet Z.: Modele systemów opieki zdrowotnej w Polsce i wybranych państwach europejskich. Zdrow Publiczne. 2008, 118, 3, 358-367.

5. Aktualne problemy i wydarzenia. Polacy o możliwych zmianach w systemie ochrony zdrowia. Komunikat z badań. Centrum Badania Opinii Społecznej, Warszawa 2007. 